\title{
PERCEPTION OF MANAGEMENT ACCOUNTING AND CONTROLLING BY POLISH AUTHORS IN PUBLICATIONS IN 1990- 2016
}

\author{
Anna Szychta \\ Justyna Dobroszek \\ University of Łódź, Poland
}

\begin{abstract}
Accounting addressed to support the management has been developed in enterprises in Poland on a wider scale since the 1990s, i.e. since the restoration of the market-based economic system after a half-a-century break. The paper aims to identify the perception of the nature and scope of management accounting and controlling by the authors in Poland since the early 1990s and demonstrate the role played in shaping this perception of accounting researchers and practitioners by two major Polish journals in this area. We conducted the management accounting and controlling literature studies including selected positions in the English, German and Polish languages and performed the review of the articles published in the Polish scientific journal Zeszyty Teoretyczne Rachunkowości and in the journal Controlling $i$ Rachunkowść Zarzadcza dedicated to practitioners. Our research allows to confirm that there is no uniform perception of the relations between management accounting and controlling among Polish researchers. We point in this respect to at least three positions. The study shows also that research in this area in Poland is dominated by the Anglo-American concept of management accounting, while business is mostly under the influence of the concept of controlling, which has its origins in German-speaking countries.
\end{abstract}

Keywords: management accounting, controlling, accounting journals, Poland

JEL code: M41, M49

\section{Introduction}

The reestablishment in Poland in the early 1990s of a market economy, after a half-a-century break caused by the functioning of the socialist, centrally-planned economy (1945-1989), and subsequent implementation and improvement of its mechanisms have had a great impact on changes in accounting regulations, practice, research and education in our country (Szychta, 2002, p. 402). Since that time management accounting (MA) has been used in business entities in Poland on a wider scale, although under the centrally-planned economy certain tasks were performed and accounting methods were used that were oriented to management purposes, and MA was taught before that by some Polish universities (e.g. in Lodz and Gdansk). This was connected with the use in some enterprises of standard costing, cost budgeting and control in responsibility centers, and implementation of internal accountability principles (Jarugowa and Marcinkowski, 1989, pp. 29-28).

Over the past 25 years MA has become a subject taught not only on economic courses in universities and other higher schools all over the country but on courses and trainings organized by various institutions and training firms. As Jaruga mentioned, development of MA in Poland remains under the influence of two approaches: "management accounting in the Anglo-American manner, and cost controlling according to the German approach" (Jaruga and Ho, 2002, p. 376). This impact applies to the business practice, teaching and publication of books and articles. The influence of these approaches is mainly manifested by the use of both the terms "management accounting" and "controlling" in practice, teaching and scientific research, differentiated perception of the relationship between MA and controlling by 
different people and the introduction in the classification of professions and specializations binding in Poland from 2010 (Regulation, 2010) into the elementary occupational group of bookkeeping and accounting specialists (code 2411) the profession of management accountant (code 241106) and the profession of controller (code 241102) (see Szychta, 2011, pp. 304-307).

During the two last decades MA practices in enterprises in Poland were the subject of many empirical research based on surveys and case studies. The research projects mainly investigated the type of cost accounting systems and MA methods used in the companies surveyed (e.g. Gierusz et al., 1996; Radek and Schwarz, 2000; Szychta, 2002, 2007, 2009; Szadziewska, 2002; Januszewski and Gierusz, 2004; Wnuk 2005; Wnuk-Pel, 2011; Dobroszek, 2016), changes in cost accounting systems and factors affecting the shape of MA in the entities studied (Sobańska and Wnuk, 2000; Sobańska, 2002), as well as the main tasks and roles of management accountants in Poland (Szychta, 2005, 2009). Empirical studies on the implementation of the controlling to companies in Poland were also conducted (e.g. Goliszewski, 2002; Brodaczewski, 2002; Dobroszek, 2014). However, empirical studies on the perception of the nature of MA and controlling and the relationship between these concepts were not performed previously in Poland.

The aim of this paper is to identify the perception (understanding) of the nature and scope of MA and controlling by the authors in Poland since the early 1990s and demonstrate the role played in shaping this perception of accounting researchers and practitioners by two major Polish journals, in which articles regarding MA and controlling are published. The authors conducted the literature studies including selected relevant subject-based literature positions in the English, German and Polish languages, and performed the review and thematic classification of the articles concerning MA and controlling, published in the scientific journal Zeszyty Teoretyczne Rachunkowości (Theoretical Journal of Accounting) and in the journal Controlling $i$ Rachunkowść Zarzadcza (Controlling and Management Accounting) designed for practitioners - controllers, analysts and managers, as well verified the subjects of habilitation dissertations and doctoral theses written in Poland since 1990.

The paper is structured as follows. Section 1 briefly presents the concepts of MA and controlling as they are explained in selected foreign literature. Section 2 contains information on perception of MA and controlling by Polish researchers and practitioners. Section 3 provides an overview of the topics of articles on MA and controlling published in two Polish journals. The last section contains concluding remarks.

\section{Management accounting and controlling - foreign approach}

In accordance with its general understanding MA is a branch of accounting which meets the information needs of managers in an organization and helps them make better decisions. Horngren (1986, p. 42) expressed its sense in a simplest way stating: "in its fullest sense, management accounting is well named. It connects management with accounting". In different languages and cultural areas specific terms are used to describe the concepts and methods being the part of this activity. In Poland the term "rachunkowość zarządcza" is used. It is the direct translation of the English-language term "MA".

Since the 1950s, when Anthony ${ }^{1}$ used the term "management accounting" for the first time (in 1955) in the title of his textbook, different authors and institutions in the Anglo-American

\footnotetext{
${ }^{1}$ R. N. Anthony published in 1955 book titled Management Accounting (Irwin, Homewood). In 1950 appeared handbook authored by W. Vatter, Managerial Accounting, Prentice Hall, New York. The latter had 18 editions (Anthony, 1989, p. 2).
} 
circles developed many definitions of MA, of which one was the definition proposed in 1958 by the Committee on Management Accounting acting within the American Accounting Association (AAA) that read (A Statement, 1966, p. 37): management accounting is ,the application of appropriate techniques and concepts in processing the historical and projected economic data of an entity to assist management in establishing plans for reasonable economic objectives and in making of rational decisions with a view toward achieving these objectives".

In definitions of MA developed in the subsequent years, e.g. by National Association of Accountants (NAA) ${ }^{2}$ in the USA in $1981^{3}$ (Statements, 2008, p. 1) and by experts of International Federation of Accountants (IFAC) in 1986 (Management, 1997, para. 3), the accent was put on listing the activities that constitute MA as a process of providing information to managers for the purpose of managing the enterprise, especially as a an information basis for decision making, related to the use of the entity's resources and accountability for its resources. There was thus a clear change in recognition of MA, compared with an earlier understanding, when it was considered as a set of techniques that should be used to provide managers with information useful for decision-making, mainly operating ones. Since the 1980s MA was considered as including the activities referred to in the definitions of the Institute of Management Accountants (IMA) and IFAC as well as preparing the reports dedicated not only to managers but also to other users, e.g. shareholders, lenders (Management, 1997, para. 4). Taking into account the dynamic changes taking place in the activities of enterprises and their socio-economic environment, IMA once again indicated in the definition (in the 1990s) the nature and scope of MA, stating that "management accounting is a value adding, continuous improvement process of planning, designing, measuring, and operating nonfinancial and financial information systems that guides management action, motivates behavior, and supports and creates the cultural values necessary to achieve an organization's strategic, tactical and operating objectives."4 .

The field of MA has evolved considerably since stating in its definition (in 1981) the nature and scope of MA. In the scientific publications since the late 1990s it was proposed that management accountants move from the transactional and menial roles, which were expressed in the definition, to the role of strategic business partners who are involved in the process of managing an enterprise. Due to enormous progress in the information technology, among other things, the original role of management accountants transformed from the information providers to designers of the management accounting system. This means that in the information chain value of the company there was a shift from the initial cell - collecting and providing data - to further cells in the chain (Statements, 2008, p. 2). Taking into account the mentioned challenges facing the management accountants working in the enterprises of rather highly developed western economies IMA in the next study in a series of Statements on Management Accounting developed a definition of MA as a profession (Statements, 2008, p. 1): Management accounting is as a profession that involves partnering in management decision making, devising planning and performance management systems, and providing expertise in financial reporting and control to assist management in the formulation and implementation of an organization's strategy.

\footnotetext{
${ }^{2}$ NAA was transformed in Institute of Management Accountants (IMA) in 1991.

${ }^{3}$ In 1981, NAA defined management accounting as: "the process of identification, measurement, accumulation, analysis, preparation, and communication of financial information used by management to plan, evaluate, and control an organization and to assure appropriate use of and accountability for its resources. Management accounting also comprises the preparation of financial reports for non-management groups such shareholders, creditors, regulatory agencies, and tax authorities".

${ }^{4}$ This definition was taken from Foster, Young (1997, p. 64).
} 
Since the 1980s in conjunction with the changes taking place in the process of business entities management and in their surroundings more and more significance was attributed to an approach to MA that explicitly highlights strategic issues and concerns, called strategic MA and distinguished from conventional or operational MA (see e.g. Wilson, 1994; Guilding et al., 2002). This approach is emphasized in the latter definition of MA.

Development MA practices in German-speaking countries is connected with the term "Controlling". This term, borrowed from English language, became popular in Germany in the early 1970s. German authors (e.g. Horváth, 2006; Ewert and Wagenhofer, 2007) emphasize that the development of controlling in enterprises in Germany and next in Austria and the German-speaking parts of Switzerland was mainly caused by an increased interest in the concepts and tools of MA of the German authors of both scientific publications and publications addressed to practitioners and large enterprises having in the German-speaking countries its subsidiaries, in which the positions of controllers were set up. Since that time there has been a continuing debate in German-speaking literature about definition and scope of controlling, as together with the dynamically developing markets and their socio-economic environment the range of controlling has expanded and the controlling systems in the enterprises have varied and evolved.

Overview of a few works (e.g. Mayer, 1986; Schweitzer and Friedl, 1992; Franz and Kajüter, 2002; Horvàth, 2006; Becker and Messner, 2005; Ewert and Wagenhofer, 2007; Schäffer and Binder, 2008), selected from plentiful publications of the German authors, confirms that understanding of the controlling substance was changing. Controlling expanded its scope. At first, controlling has been narrowly defined as cost accounting (or internal accounting), budgeting and reporting. Next it started to encompass planning and management control at an operative and a strategic level (e.g. Becker and Messner, 2005, p. 418). Yet in a broader sense controlling covers "overall managerial coordination of management accounting, planning and control, organizational structure and the firm's incentive system" (Schäffer and Binder, 2008, p. 35). In the past the prevailing approach was the one claiming that the role of controlling is to support enterprise management. This approach was then replaced by alternative concepts, e.g. claiming that the controlling is set to ensure the rationality of management as a result of the implementation of its tasks (Ewert and Wagenhofer, 2007, p. 1036). Due to particular functions performed by controlling and the methods used in German-speaking countries there exist two types of controlling: operational controlling and strategic controlling (e.g. Mayer, 1986), similarly as in the Anglo-American approach where the distinction is made between operational MA and strategic MA. This is not the only division of controlling. In contrast to MA, the concept of controlling has an impact on different functional areas in enterprises. Küpper (2008, pp. 463-464) distinguishes controlling of marketing, controlling of logistics, HR controlling, controlling of investments or controlling of university. Furthermore, the German literature describes aspects of controlling of services (Frank-Jürgen, 2003), environmental controlling (Schulz et al., 1993), procurement controlling (Piontek, 2012), controlling of projects (Fiedler, 2014) or subsidiary controlling and group controlling (Paul, 2014). The separation of such areas of controlling influenced a wide range of subjects in the field of controlling at the German universities (see Dobroszek and Zarzycka, 2015). This issue does not exist in the context of MA.

In the recently published statement of the International Controller Association (ICV) and the International Group of Controlling (IGC), experts from these organizations expressed the essence of controlling in the following way: "Controlling is a management activity. It means being objective-driven and directing all decisions towards achieving this end. Consequently, planning and calculative practices, as well as monitoring and control, are of central 
importance. This applies to each individual management decision as well as to the management of the corporation as a whole" (Perspective, 2012, p. 2). "There can be no Controlling without management. Since Controlling is so important and complex, it makes sense to support managers in this task. This support is largely provided by controllers. Therefore, it is the interaction between managers and controllers that constitutes Controlling (...)" (Perspective, 2012, p. 4). Controlling is therefore the joint part of activity of manager and controller in decision-making. It is not only relevant for profit-oriented companies but also for not-for-profit and public organizations.

As pointed out Schäffer and Binder (2008, p. 35), despite many years of discussions in the German-speaking countries "there is little disagreement in academia and practice on the core issues of controlling. They overlap widely with what is internationally considered management accounting and management control".

In the light of the cited opinions and definitions it is reasonable to treat controlling and MA in a tool based approach as a scope of knowledge and practical activities overlapping to a great extent, which is also confirmed among others by Ewert and Wagenhofer (2007, p. 1037). On the other hand, as it was widely presented by Schäffer and Binder (2008, p. 34), "controlling has become an established discipline of business administration (Betriebswirtschaftslehre) in German-speaking countries and can be considered a comparatively young field that has traditionally been highly practice-oriented, but also self-referential and for the most part not integrated into the international community." Thus, since the 1970s MA and management control research in German-speaking countries have developed in a specific way.

Information about MA concepts and practices originating from Germanic and Anglophone countries exerted a varied impact on perception of MA by different groups of people interested in MA in Poland in the last 25 years.

\section{Management accounting and controlling - perception in Poland}

Starting from the early 1990s, many textbooks, articles and conference papers dealing with MA have been published in Poland and their number is growing steadily. Research in this field has been expanded and intensified at many public universities and other higher schools. Since the beginning of the systemic transformation MA was explained in the Polish scientific publications and academic textbooks in accordance with its characteristics evident in the English-language publications and evolving perception of its nature presented, among others, in the previously cited definitions. The huge contribution to popularization of the knowledge on this subject was made by Professor A. Jaruga (e.g. 1993, 1995, 1997a, b, 1999), who since the 1970s has collaborated with the western accounting researchers.

Simultaneously, the literature of the subject began to explain the nature and methods of controlling. Discussion about the concepts and scope of controlling which took place in the German-speaking countries moved to the Polish scientific and consulting community, but it was not so intense as in Germany - western neighbor of Poland. At the beginning of the 1990s the attempts to explain the nature and tasks of controlling were made by e.g. Goliszewski (1990), Sawicki (1992), Szychta (1992) and Sobańska (1992). Goliszewski (1990, p. 9) stated that controlling is the process of steering (oriented at an enterprise's result) realized by planning, control and reporting. Sawicki (1992, p. 24 and p. 27) explained that controlling is "to support management in such a way that it combines (integrates) the planning, control and information", it is "an elementary component (subsystem) of the management, steering the activities of an enterprise in the direction of a target by means of coordinating the whole process of planning, disposition and control, and providing useful information. While Szychta (1992, p. 32) wrote that controlling is the "concept of steering an 
enterprise based on financial accounting and cost accounting and directed to functioning of the enterprise in the future. The task of controlling is to steer the enterprise through planning, control and communication of information". On the other hand, Sobańska (1992, p. 9) stressed that the concept of controlling "was built on the basis of a methodology of creating information by financial accounting and management accounting with a focus on the future periods".

Different explanations of the nature of controlling in the Polish authors' publications (e.g. Nowak, 1996, 2011; Kiziukiewicz, 2003; Fjałkowska, 2003; Sobańska, 2010; Dobroszek and Szychta, 2010) can be reduced to two essential, synthetic approaches. Controlling is:

1) a tool supporting management or over-function management instrument;

2) system of steering and coordination in an enterprise.

Knowledge about the nature, methods and accounting organization concentrated on the needs of management have come since the beginning of transformation in Poland from abroad, not only from two language areas but also two ways - academic and practical-consulting way. Academic way consisted of considering the teaching and research publications of the Englishspeaking and German-speaking authors by Polish authors writing their textbooks and scientific papers on MA and controlling, publishing in Polish books and articles translated from English and German (e.g. Mann and Mayer, 1992; Vollmuth, 1993; Drury, 1995; Kaplan and Cooper, 2000; Kaplan and Norton, 2001), initiating and broadening cooperation with foreign research centers (e.g. by the British program Know How Fund - the Development of Accounting in Poland performed by several universities in the period 1991-1995, led by Professor A. Jaruga on behalf of the Minister of Science and Higher Education in Poland).

Practical and consulting way of disseminating and getting the knowledge and skills in the field in question was based firstly on implementing the new methods in privatized enterprises or subsidiaries of foreign companies, and secondly, on open training sessions and courses organized by the domestic training and consulting companies and the in-house training for employees of the concrete enterprises in which MA or controlling system was planned or already implemented.

The influence of the information provided to Polish enterprises about the Anglo-American concepts of MA and controlling derived mainly from Germany led to the awareness in practice (particularly in managers and accountants) that these are two different concepts, (Sobańska 2010, p. 97; Sobańska et al., 2010, p. 61), therefore in some enterprises both the controlling department and management accounting department were set up (Szychta, 2009, p. 82).

Scientific research carried out so far in Poland (e.g. Goliszewski, 2002; Szychta, 2007, 2009) confirm that number of employees performing management accounting tasks in business entities is growing steadily. Their posts are given various titles such as controller, financial controller, financial analyst, expert in analysis and planning, and management accountants. As regards the organization of MA in the enterprises in Poland, the influence of German tradition is stronger than the Anglo-American tradition, which is indicated by a greater number of controlling departments than MA departments in the surveyed companies.

Polish authors of scientific papers and popular science publications do not share uniform opinion on the relation between MA and controlling. One can point in this respect to at least three positions:

1) controlling is wider than MA;

2) MA and controlling have common elements but MA is for instance a tool or information basis for controlling; 
3) MA and controlling overlap.

The first group of the authors is represented by, for instance, Brzezin (1998). After analyzing several definitions of controlling, formulated by the German authors, Brzezin (1998, p. 6), proposed the following own definition: "Controlling is a profit oriented decentralized system of planning, steering and control, which widely uses methodology of management accounting and modern methodology of financial management". Explaining the relationship between MA and controlling the author claimed that controlling "is a broader concept because it creates management subsystem focused on profit-making through creating positive relations between the aims and means used to achieve these aims. And MA "is to secure" modernly prepared economic account, which will be used both in planning and making ad hoc and strategic decisions".

The second of these views is supported by for example Sawicki (1992), Olech (1999) Kiziukiewicz (2003) and Świderska (2010). When referring to the characteristics of financial accounting and management accounting Sawicki (1992, p. 32) concluded: "there are close links between controlling and accounting" because the accounting of an enterprise is "an important tool supporting controlling" (p. 33) and "the controlling is the most closely related to management accounting which developed from cost accounting" (p. 28). However, according to Olech $(1999$, p. 2) MA has become the first toolbox for controlling. On the other hand, Swiderska (2010, p. 25) believes that MA and controlling "use the same tools of information, but controlling is a kind of philosophy of the use of information from management accounting to effectively support the work of a controller", and accounting, especially MA, is the information base for the work of a controller. She believes that MA realizing two main objectives (providing information to management and participation in the management process) becomes an integral part of the key management processes in an organization - planning, organizing, leadership and control. It supports managerial operations - decision making, communication and change management. Kiziukiewicz (2003, p. 275) interprets yet this relationship differently claiming that the MA system and controlling system have "common areas and activity objectives. The difference remains in their philosophy management accounting is to help in decision problems solving and achieving the aim from the substantive point of view and controlling is to help in achieving the aim by efficient management system."

Jaruga (1995) and Sobańska (2010) are primarily the supporters of the third method of determining the relationship between MA and controlling. On the basis of the characteristic of controlling and MA concepts Sobańska (2010, p. 98) concludes that "the objectives, tasks, methods and techniques do not show now any differences, even specialists performing these professions in reality are named identically i.e. as controllers". In the life of the large international companies with the German and Anglo-American capital, in which both concepts are present - we do not observe any differences or problems in cooperation between these specialists". The author emphasizes that "controlling is only historically and culturally conditioned name of the knowledge and practice of management accounting" and in her publications she often uses the term "management accounting/controlling". This approach to the perception of the relationship between MA and controlling was supported by the Management Accounting and Controlling Commission ${ }^{5}$, operating under the Research Council of the Accountants Association in Poland (AAP) in the years 2003-2015 (Sobańska et al., 2010).

\footnotetext{
${ }^{5}$ This Commission took initiatives to develop science and MA practice in Poland. After changing its priorities Scientific Council of AAP did not establish the Commission in 2015 for the next term of office.
} 
In the above opinions we cannot find explanations of the scope of controlling which provide German researchers Schäffer and Binder (2008, p. 35), stating that the issues of controlling "overlap widely with what is internationally considered management accounting and management control", which indicates that controlling goes beyond the scope of MA.

In the mentioned opinions of the Polish accounting researchers, who also usually held the functions of advisors to managers or designers of MA system or controlling system for companies, it is visible that they variously perceive relationship between MA and controlling, and so they influence the shape and the image of MA and controlling among practitioners of accounting and management in Poland.

\section{Management accounting and controlling on the pages of leading journals in Poland}

In the perception of the nature and scope of the MA and controlling by the Polish practitioners and accounting and management researchers an important role was played by articles published in the scientific and professional journals in which conceptual and application issues of MA and controlling were explained. In our opinion the greatest impact in this regard belonged to two Polish journals - Zeszyty Teoretyczne Rachunkowości (Theoretical Journal of Accounting - in brief ZTR) and Controlling $i$ Rachunkowość Zarządcza (Controlling and Management Accounting - in brief CRZ). Both magazines are nationwide and are relatively long and systematically issued. ZTR is a scientific periodical published since 1977 and CRZ is a monthly magazine designed for practitioners, issued since 1999.

\subsection{The journal Zeszyty Teoretyczne Rachunkowości (ZTR)}

The journal ZTR has been published by the Research Council of Accountants Association in Poland (AAP) since 1977. This journal was firstly (until 2000) entitled Zeszyty Teoretyczne Rady Naukowej (The Theoretical Journal of Research Council of AAP - ZTRN). The purpose of ZTR is to publish articles written by Polish and foreign authors, thus contributing to the development of accounting studies. ZTR provide a platform for presenting concepts, analyses and results of research on past and current solutions in the areas of accounting theory, didactics and practice. In the last few years, in ZTR were published articles written in both Polish and English languages ${ }^{6}$. ZTR were published in two different political and socioeconomic periods in Poland (1977-1989 and 1990-2016), so the analysis of the topics of the articles published in these periods allows to identify certain research trends in accounting, including the field of MA.

The authors of this article conducted a review of the content of all (147) issues of ZTR, which were published between 1977 and 2016, i.e. from volume 1 issued in 1977 to volume 90 (146) prepared for publication in 2016 and the volume issued in 1985 as a special edition without a number. In total there were about 1890 scientific articles published in ZTR, including 327 on MA and controlling, which amounts to about $17 \%$ of the total number. It means that the majority of the articles referred to financial accounting and auditing.

\footnotetext{
${ }^{6}$ See more: Zeszyty Teoretyczne Rachunkowości, http://ztr.skwp.pl/index.php?p=1. Since the end of 1990s, ZTR has been published on almost regular basis like a quarterly journal. This is due to publishing the so called 'regular' volumes 3-4 times a year. Apart from these, two special (thematic) volumes a year are additionally published. ZTR are a valued Polish scientific periodical devoted to accountancy. Its quality is confirmed by the high rank which has been granted for many years by the Ministry of Science and Higher Education on the list B of the register of scientific journals in Poland. In 2013-2014, ZTR was given 8 points (maximum was 10) on this list, and in 2015 it received 15 points in the scale $1-15$.
} 
Having in mind the main goal of this article, the authors focused their attention on the texts whose topics revolve around MA and controlling. The review of the journal's content and the analysis of the articles were conducted in the following three sub-periods encompassing:

1) the years 1977-1989, i.e. the period of centrally planned economy, when 16 volumes of ZTRN were issued: No. 1 - No. 15 and a special issue of 1985 ;

2) the years 1990-2000, i.e. the period of socio-economic transformation, when 42 volumes of ZTRN were issued: No. 16 - No. 56 and ZTR No. (1) 57;

3 ) the years 2001-2016, called the period of reinforcement of market economy in Poland, when 89 volumes of ZTR were issued: from No. 2(58) to No. 90 (146).

The above breakdown results from political and socio-economic changes in Poland. The first sub-period covers the last years of the policy of centrally planned socialist economy. The second sub-period encompasses the first years when market economy was reestablished in Poland, including, among others, privatization of national enterprises and building of capital market. The first two sub-periods fall on the 20th century. The third sub-period beginning along with the 21 st century is characterized by the strong influence exerted on market economy in Poland by globalization processes, growing influence of international and transnational companies and integration of domestic economy with the European market (Poland joined the European Union in 2004).

In the further analysis and classification of the articles' topics concerning MA and controlling which appeared in ZTR the authors focused on the texts published in the second and the third sub-periods, however, to maintain the consistency of presentation also the first sub-period was included. The review of 147 issues of ZTR shows that during 40 years when the journal was published, it contained 327 scientific articles which relate to cost accounting, MA and controlling. Most of them (303 articles, i.e. approx. 92\%) refers to the concept of MA, and only in 25 texts the authors wrote about the concept of controlling (table 1). This fact confirms that the Polish accounting scientists are generally under the influence of AngloAmerican trends - they more willingly use the term MA in their works.

Table 1. The number of articles in ZTR concerning MA and controlling in the three subperiods in the years 1977-2016

\begin{tabular}{|c|c|c|c|}
\hline Sub-periods of the analysis & $\begin{array}{c}\text { Management } \\
\text { accounting (MA) }\end{array}$ & Controlling (C) & $\begin{array}{c}\text { Total } \\
\text { MA \& C }\end{array}$ \\
\hline 1977-1989: Period of planned economy & 36 & 0 & 36 \\
\hline $\begin{array}{l}\text { 1990-2000: Period of socio-economic } \\
\text { transformation }\end{array}$ & 93 & 17 & 110 \\
\hline $\begin{array}{l}\text { 2001-2016: Period of reinforcement of } \\
\text { market economy }\end{array}$ & 174 & 8 & 182 \\
\hline Total & 303 & 25 & $328^{\mathrm{a}}$ \\
\hline
\end{tabular}

a In the years 1977-2016, 327 articles were published in ZTR, but one of them (in volume 56 of 2000) referred to both MA and controlling, so it was assigned in the table to both topics, which resulted in the increase of the total number by 1 .

In the period of the last 13 years of centrally planned economy in Poland, only 36 articles which presented the issues of cost accounting were published in ZTR, while controlling was not a subject of scientific description. It is justified because this concept was only starting gaining influence in practice and didactics in German-speaking countries and it could have been known in Poland only to a narrow group of academic workers who were in contact with German professors. The systemic transformation in 1989 gave rise to the growth of publications, referring mainly to MA and - although to a lesser extent - to controlling. The use of the term "controlling" in the titles of publications was connected with the fact that 
German companies started operating in the Polish market and German-speaking investors made various investments in Poland. So the need to explain the concept of controlling arose.

The biggest number (182) of articles concerning MA was published in ZTR in the third subperiod of the analysis. They constituted nearly $56 \%$ of all texts in the scope of MA and controlling published within 40 years of publishing this magazine. It was caused by the development of MA in business entities, which on the one hand needed the knowledge of new concepts and methods supporting managers; and on the other hand such companies could provide scientists with greater possibilities to conduct empirical research (more source materials, better access to them). Besides, the mobility of Polish scientists increased, and thanks to open foreign universities and unlimited access to information (the Internet, data bases) they could deepen their knowledge and learn about new concepts and aspects of MA and controlling. Such a situation is not unique to Poland, but could be observed also in other countries of Eastern and Central Europe, such as Estonia and Lithuania, which have gone through the process of systemic transformation.

Table 2. Thematic groups of articles on MA and controlling in ZTR in the years 1977-2016

\begin{tabular}{|c|c|c|c|c|c|c|}
\hline \multirow[b]{3}{*}{ No. } & \multirow[b]{3}{*}{ Topic } & \multirow{2}{*}{\multicolumn{2}{|c|}{$\begin{array}{l}\text { All articles } \\
\text { in the years } \\
1977-2016\end{array}$}} & \multicolumn{3}{|c|}{ Number of articles in the years: } \\
\hline & & & & \multirow{2}{*}{\begin{tabular}{|c|}
$1977-$ \\
1989 \\
Period of \\
planned \\
economy
\end{tabular}} & \multirow{2}{*}{\begin{tabular}{|c|}
$1990-2000$ \\
Period of \\
socio-economic \\
transformation
\end{tabular}} & \multirow{2}{*}{\begin{tabular}{|c|}
$2001-2016$ \\
Period of \\
reinforcement \\
of market \\
economy
\end{tabular}} \\
\hline & & Number & $\%$ & & & \\
\hline 1. & $\begin{array}{l}\text { Nature, development and implementation } \\
\text { of management accounting (51 articles) } \\
\text { and controlling ( } 25 \text { articles) }\end{array}$ & 76 & 23.2 & - & 16 & 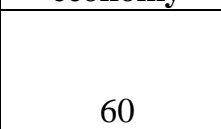 \\
\hline 2. & $\begin{array}{l}\text { Traditional costing systems (absorption } \\
\text { costing and variable costing based on } \\
\text { actual costs) }\end{array}$ & 47 & 14.4 & 10 & 22 & 15 \\
\hline 3. & $\begin{array}{l}\text { Activity-Based Costing and Activity- } \\
\text { Based Management }\end{array}$ & 34 & 10.4 & 0 & 16 & 18 \\
\hline 4. & Performance measurement & 33 & 10.1 & 2 & 7 & 24 \\
\hline 5. & Costs and their concepts & 31 & 9.5 & 4 & 11 & 16 \\
\hline 6. & Budgeting & 18 & 5.5 & 1 & 11 & 6 \\
\hline 7. & Quality costs and environmental costs & 16 & 4.9 & 6 & 4 & 6 \\
\hline 8. & CVP analysis & 15 & 4.6 & 2 & 5 & 8 \\
\hline 9. & Methods of cost calculation & 12 & 3.6 & 7 & 4 & 1 \\
\hline 10. & $\begin{array}{l}\text { Life-cycle costing, target costing and } \\
\text { kaizen costing }\end{array}$ & 10 & 3.1 & 0 & 5 & 5 \\
\hline 11. & Transfer pricing & 9 & 2.8 & 0 & 4 & 5 \\
\hline 12. & Standard costing & 8 & 2.4 & 4 & 0 & 4 \\
\hline 13. & Decision making in the short term & 7 & 2.1 & 0 & 2 & 5 \\
\hline 14. & IT aspects in management accounting & 4 & 1.2 & 0 & 0 & 4 \\
\hline 15. & Capital budgeting & 3 & 0.9 & 0 & 2 & 1 \\
\hline 16. & Management accounting and IRFS & 2 & 0.6 & 0 & 0 & 2 \\
\hline 17. & $\begin{array}{l}\text { Lean management and management } \\
\text { accounting }\end{array}$ & 2 & 0.6 & 0 & 0 & 2 \\
\hline 18. & Total & 327 & \begin{tabular}{|l|}
100 \\
\end{tabular} & 36 & 109 & 182 \\
\hline
\end{tabular}

In order to determine the detailed topics of articles concerning MA and controlling published in ZTR in the three distinguished sub-periods they were divided into 17 thematic groups, shown in table 2. The division into thematic categories applied is similar to the topics in Polish academic handbooks on management accounting (e.g. Sobańska, ed., 2010; Świderska ed., 2010; Jaruga et al., 2014). If the article referred to more than one thematic group, it was assigned to one group on the basis of a subjective decision. 
The review of the articles in ZTR reveals that the biggest number of texts $(76$, which is 23.2\%) was focused on different theoretical aspects of the development of MA and controlling or their applications in practice (presentation of various research results on implementation of MA and controlling methods). The articles exploring these topics were firstly published in the period of socio-economic changes in Poland (16 articles), and their number increased nearly fourfold in last 16 years. Traditional costing systems (full costing, variable costing, multi-stage and multi-block variable costing based on actual costs) are the second most frequently chosen topic by the authors of articles in ZTR. The scientists were similarly interested in Activity-Based Costing and Activity-Based Management, performance measurement, including by way of Balanced Scorecard, as well as costs and their concepts, however, in the third sub-period of publishing ZTR performance management was prevailing. Budgeting attracted the interest of scientists in 18 articles; most of them (11 articles) were published in the years 1990-2000. It was connected with the characteristic of the rules and different aspects of implementation of the conventional MA method (i.e. budgeting) which was most frequently applied and subject to empirical research in the western countries in the late 20th century (see e.g. Covaleski et al., 2003). In comparison to budgeting less attention was devoted to the issues of CVP analysis, cost calculation methods, short term decision making, environmental costs and quality costs as well as methods of strategic MA (life-cycle costing, target costing and kaizen costing). Such classic issues of MA as standard costing, transfer pricing and capital budgeting were rarely explored in articles published in ZTR.

The review of the topics of articles in this scientific journal shows that in the period of planned economy in Poland authors were focused on such issues as: costing systems, methods of cost calculations, environmental costs and quality costs. While in the period of systemic transformation and the next period the topics that attracted the biggest attention included new concepts and methods of MA, which a few years earlier had appeared in foreign literature, such as strategic MA, ABC, ABM, target costing, BSC and lean accounting. The concept and application of controlling was present in the scientific articles in ZTR rather rarely (in $7.65 \%$ of all articles).

\subsection{The journal Controlling $i$ Rachunkowość Zarządcza (CRZ)}

The journal CRZ is a monthly magazine aimed at practitioners, including financial directors, chief accountants, controllers, financial analysts and managers. It contains popular science articles, advice and opinions of experts in the field of controlling, management accounting and management. CRZ features, among others, "case studies describing implementation of controlling tools in the enterprises operating in the market, advice of the most prominent Polish and foreign experts, descriptions of IT tools supporting controlling and budgeting, modern methods of costing and management accounting" ( $O$ miesięczniku, 2016). The magazine has been issued since 1999, although it first issue was published in December 1998. In the late 1999 three other numbers of CRZ were published, and since 2000 the magazine has been issued regularly as a monthly journal. Until 2003 it came out only in paper form, and after this year it had both paper and electronic version. The characteristic feature of CRZ is that mostly the texts contained in this journal are written by practitioners for practitioners.

In order to identify the detailed topics popularized among practitioners in Poland in CRZ, the authors conducted a review of the magazine's content beginning from the promotional edition issued in 1998 to the latest issue of September 2016. The content was reviewed in 203 issues of the journal. The authors took into consideration texts in such thematic sections distinguished by the editors as controlling, management accounting, strategies and management, experience and knowledge of experts, controllers' tools, special supplements, 
investment financing. The sections informing about new books, conferences and other events important for readers as well as the manager's dictionary were omitted.

The authors assigned over 2200 texts to 18 thematic groups, including 15 analogical groups as in ZTR and three groups called:

1) controlling: the articles presenting concepts, types, systems and implementations of controlling in enterprises;

2) development of management accounting: texts on the essence and evolution of management accounting and management accountants;

3) other topics, i.e. referring to the concept and methods of management, finance, financial management and internal control.

The classification of certain number of articles to one group was subjective because sometimes authors presented issues referring to two or three topics in one article. The quantitative list of texts published during 18 years in CRZ broken down by thematic groups is shown in table 3.

Table 3. Thematic groups of the articles published in CRZ in the years 1998-2016

\begin{tabular}{|l|l|c|c|}
\hline No. & \multicolumn{1}{|c|}{ Thematic groups } & $\begin{array}{c}\text { Number } \\
\text { of articles }\end{array}$ & \multicolumn{1}{|c|}{$\%$} \\
\hline 1. & IT aspects in controlling and management accounting & 318 & 14.34 \\
\hline 2. & Controlling (concepts and implementation) & $\mathbf{2 8 6}$ & $\mathbf{1 2 . 8 9}$ \\
\hline 3 & Performance measurement (including BSC - 150 articles) & 269 & 12.13 \\
\hline 4. & Budgeting and operational planning & 266 & 11.99 \\
\hline 5. & Activity-Based Costing and Activity-Based Management & 126 & 5.68 \\
\hline 6. & Decision making in the short term & 85 & 3.83 \\
\hline 7. & Cost calculation methods, pricing methods and cost settlement of auxiliary activities & 85 & 3.83 \\
\hline 8. & Costs and their concepts & 79 & 3.56 \\
\hline 9. & Traditional costing systems (absorption costing and variable costing based on & 77 & 3.47 \\
\hline 10. & Development of management accounting & $\mathbf{3 0}$ & $\mathbf{1 . 3 5}$ \\
\hline 11. & Standard costing & 17 & 0.77 \\
\hline 12. & Life-cycle costing, target costing and kaizen costing & 17 & 0.77 \\
\hline 13. & CVP analysis & 14 & 0.63 \\
\hline 14 & Quality costs and environmental costs & 14 & 0.63 \\
\hline 15. & Transfer pricing & 12 & 0.54 \\
\hline 16. & Capital budgeting & 8 & 0.36 \\
\hline 17. & Management accounting and IRFS & 4 & 0.18 \\
\hline 18. & Other issues & $\mathbf{2 2 1 8}$ & $\mathbf{1 0 0}$ \\
\hline $\mathbf{1 9}$ & Total & 511 \\
\hline
\end{tabular}

The quantitative list of topics of articles in CRZ shows that the articles classified as other issues, i.e. those concerning finance and management of business entities, has the biggest share $(23.04 \%)$ in all topics. The issues connected with MA and controlling were touched upon in 1707 articles, which constitutes nearly $77 \%$ of all the articles in this magazine. In this field, the authors mostly wrote about IT aspects of MA and controlling. The second most frequent subject (explored in 286 texts) was controlling, and especially its concepts, tools and application in Polish enterprises. The authors used the word ,controlling” in almost $13 \%$ of all the articles, while the issues of development of MA and management accountants were considered in 30 articles (1.35\% of the total number). The third place in the list of topics went 
to performance measurement of business entities, which was discussed in 269 articles, including 150 texts about different aspects of performance measurement with the use of Balanced Scorecard (BSC). A similar level of authors' attention was obtained by operational budgeting and planning in enterprises (266 texts). Among the five thematic groups with the biggest number of articles there were also the issues of Activity-Based Costing and ActivityBased Management (126 texts). Other thematic groups comprised much fewer articles.

In comparison with the area of MA and controlling in ZTR, the authors writing for CRZ were concentrated on presenting ways to support controlling with IT tools, description of controlling implementation in different cases and performance measurement in enterprises, and only to a small extent were they interested in concepts and development of MA $(1.35 \%$ of all articles).

\section{Concluding remarks}

The review conducted and the list of topics of articles published in ZTR and CRZ confirms that scientific workers in Poland since the 1990s in most cases have used the term "management accounting" and carried out research within the concept of MA. This tendency is also proved by the review of titles of doctoral and habilitation (postdoctoral) theses written at Polish universities ${ }^{7}$ in the years 1990-2012. On the basis of the list of these papers prepared by Sojak et al. (2007) and Sojak and Czerska (2013), the authors of this article calculated that in the years 1990-2012, i.e. in the period of systemic transformation and development of market economy in Poland, 49 monographs in the field of accounting were published, which constituted a basis for granting a habilitated doctor degree in the field of economics. 20 out of these monographs referred to costing, management accounting and controlling. Only in three titles of habilitation publications the term "controlling" was used, and four monographs used the term "management accounting". In other books different terms were applied, such as "costing", "activity-based costing", "cost management" and "budgeting".

Doctoral theses referring explicitly to the problems of MA and controlling appeared, similarly to habilitations, in the second half of the 1990s. By 2012, 116 doctoral theses with this topic were defended. The term "controlling" was included in the titles of $25 \mathrm{PhD}$ theses. The works using this term were written mainly under the supervision of professors in the Wrockaw University of Economics (16 works). At other universities this term was used only in few titles of $\mathrm{PhD}$ theses written in accountancy departments (Czestochowa University of Technology - 3, University of Szczecin - 2, Poznań University of Economics and Business 2, University of Lodz - 1, University of Warmia and Mazury - 1). In other academic centers titles of doctoral theses contained the terms "cost accounting", "management accounting" and "cost management".

As it univocally transpires from the topics of the scientific journal ZTR as well as doctoral and habilitation theses written by Polish scientific workers and $\mathrm{PhD}$ students dealing with accountancy in the period of the last quarter of the century, the concept of controlling is present in scientific research not as often as the concept of management accounting. On the other hand, the authors of the texts published in CRZ, i.e. a leading magazine for practitioners, who are mostly practitioners or "trainers" of accounting and management, are more focused on controlling. In Polish companies we can observe a high diversity in application of names of departments and positions supporting the process of management, however controlling departments or units prevail. It is confirmed also by the review of job

\footnotetext{
${ }^{7}$ The review covered the work written in 17 public higher education institutions and the Kozminski University, a leading non-public higher education institution, which have conducted scientific research in this field at least since the late 90 s of the 20th century.
} 
advertisements on various websites (e.g. pracuj.pl). Companies mainly establish controlling departments, and specialists working there are called controllers, rather than management accountants.

The opinions and comparisons presented in this article allow us to confirm that scientific research on accounting in Poland is dominated by the Anglo-American concept of MA, while business is mostly under the influence of the concept of controlling, which has its origins in German-speaking countries. There is no uniform perception of the relations between MA and controlling among Polish scientists. Different opinions of Polish authors about this relations mainly result from different definitions of controlling in German-language literature, from which they derive knowledge. The large range of opinions among Polish writers, some of whom cooperate with practitioners or are practitioners in business themselves, impacts a multi-faceted image of controlling and MA created in Polish enterprises.

\section{References}

Anthony R. N. (1989). Reminiscences About Management Accounting. Journal of Management Accounting Research, vol. 1, Fall, pp. 1-20.

A Statement of Basic Accounting Theory (1966). Sarasota, Florida: American Accounting Association.

Becker A. (2004). Jeneseits des Kerns des Controlling: Management Accounting as Social and Institutional Practice. Controlling \& Management, no. 2, pp. 95-107.

Becker A., Messner M. (2005). After Scandals: A German-Speaking Perspective on Management Accounting Research and Education. European Accounting Research, vol. 14, no. 2, pp. 417-427.

Brodaczewski R. (2002). Controlling w polskich przedsiębiorstwach. Controlling $i$ Rachunkowości Zarzadcza, no. 12, pp. 22-26.

Covaleski M. A., Evans III J. H., Luft J. L., Schields M. D. (2003). Budgeting Research: Three Theoretical Perspectives and Criteria for Selective Integration. Journal of management Accounting Research, vol. 15, pp. 3-49.

Dobroszek J. (2014). Pomiar kosztów i wyników w systemie controlling w przedsiębiorstwach usług logistycznych. PhD dissertation, Łódź: Uniwersytet Łódzki.

Dobroszek J. (2016). Rachunkowość zarządcza w zarządzaniu łańcuchem dostaw w świetle wyników badań literaturowych i ankietowych. Zeszyty Teoretyczne Rachunkowości, no. 89 (145), pp. 29-54.

Dobroszek J., Szychta A. (2009) "Koncepcyjny i ewolucyjny wymiar controllingu”, Zeszyty Teoretyczne Rachunkowości, no. 52 (108), pp. 21-48.

Dobroszek J., Zarzycka E. (2015). Education in the area of management accounting/controlling in Poland and Germany. Social Sciences (Socialiniai mokslai), vol. 87, no. 1 , pp. 54-63.

Drury C. (1995). Rachunek kosztów. Warszawa: PWN.

Ewert R., Wagenhofer A. (2007). Management Accounting Theory and Practice in GermanSpeaking Countries. In: Chapman Ch. S., Hopwood A. G., Shields M. D. (eds.), Handbook of Management Accounting Research, vol. 2, Amsterdam: Elsevier, pp. 1035-1070.

Fiedler R. (2014). Controlling von Projekten. Wiesbaden: Springer. 
Fjałkowska D. (2003). Moda na controlling. Controlling i Rachunkowości Zarządcza, no. 2. IXVI.

Foster G., Young S. M. (1997). Frontiers of Management Accounting Research. Journal of Management Accounting Research, vol. 9, pp. 63-77.

Franz K. P., Kajüter P. (2002). Zum Kern des Controllings, Sonderdruck aus: J. Weber, B. Hirsch (Hrsg.). Controlling als akademische Disziplin, Wiesbaden: Eine Bestandsaufnahme, pp. $123-\mathrm{m} 130$.

Gierusz J., Kujawski A., Kujawski L. (1996). Stan obecny oraz kierunki ewolucji rachunku kosztów i rachunkowości zarządczej w przedsiębiorstwach Polski północnej. Zeszyty Teoretyczne Rady Naukowej, no. 35, pp. 41-47.

Goliszewski J. (1990). Controlling - system koordynacji przedsiębiorstwa. Przegląd Organizacji, no. 8-9.

Goliszewski J. (2002). Rozwój controllingu w Polsce na podstawie ogłoszeń o pracę. Controlling i Rachunkowość Zarządcza, no. 6, pp. 21-26.

Guilding C., Cravens K. S., Tayles M. (2000). An international comparison of strategic management accounting practices. Management Accounting Research, vol. 11, no. 1, 113136.

Horngren Ch. T. (1986). Cost and management accounting: yesterday and today. In: Research and Current Issues in Management Accounting, eds. M. Bromwich, A. G. Hopwood. London: Pitman Publishing, pp. 31-43.

Horváth P. (2006). Controlling, 10 ed. München: Verlag Franz Vahlen.

Januszewski A., Gierusz J. (2004). Ocena przydatności rachunku kosztów pełnych i rachunku kosztów zmiennych w zarządzaniu - wyniki badań empirycznych. Zeszyty Teoretyczne Rachunkowości, no. 19 (75), pp. 42-61.

Jaruga A. (1993). Kierunki zmian funkcji rachunkowości w procesie przechodzenia do gospodarki rynkowej. Acta Universitatis Lodziensis. Folia Oeconomica, no. 127, pp. 3-12.

Jaruga A. (1995). Rachunek kosztów, rachunkowość zarządcza - wprowadzenie, [in:] Jaruga A., ed., Rachunek kosztów i rachunkowość zarządcza. Warszawa: Centralny Ośrodek Szkolenia Zawodowego SKwP.

Jaruga A. (1997a). Rachunkowość zarządcza - od systemu informacji do współudziału w zarządzaniu. Zeszyty Teoretyczne Rady Naukowej, no. 41, pp. 129-136.

Jaruga A. (1997b). Rachunkowość zarządcza ostatniej dekady: od funkcji informacyjnej do współudziału w zarządzaniu. In: A. A. Jaruga, W. A. Nowak, A. Szychta, Zarządzanie kosztami w praktyce światowej, Gdańsk: Oddk, pp. 7-15.

Jaruga A. (1999). Rachunkowość zarządcza na świecie: wczoraj - dziś - jutro. Controlling $i$ Rachunkowość Zarządcza w Firmie, egzemplarz promocyjny (promotional copy), pp. 2-3.

Jaruga A., Ho S. S. M. (2002), Management accounting in transitional economies. Management Accounting Research, vol. 13, no. 4, pp. 375-378.

Jaruga A., Kabalski P., Szychta A. (2014). Rachunkowość zarzadcza, 2nd ed., Warszawa: Oficyna a Wolters Kluwer business.

Jarugowa A., Marcinkowski J. (1989). Uwagi do ewolucji funkcji rachunkowości w Polsce. Acta Universitatis Lodziensis. Folia Oeconomica, no. 88, pp. 19-29. 
Kaplan R. S., Cooper R. (2000). Zarządzanie kosztami i efektywnością. Kraków: Dom Wydawniczy ABC.

Kaplan R. S., Norton D. P. (2001). Strategiczna karta wyników. Jak przełożyć strategię na działanie. Warszawa: PWN.

Kiziukiewicz T. (2003). Rachunkowość zarządza jako instrument zarządzania. In: Kiziukiewicz T., ed., Zasady rachunkowości zarządczej. Warszawa: Polskie Wydawnictwo Ekonomiczne.

Küpper H.-U. (2008). Controlling Konzeption, Aufgaben, Instrumente. Stuttgart: SchäfferPoeschel Verlag.

Management Accounting Concepts. Proposed Revision to Statement on International Management Practice \# 1. (1997). Financial and Management Accounting Committee, Exposure Draft, IFAC, New York.

Management Accounting Concepts. International Management Accounting Practice Statement (1998). New York: Financial and Management Accounting Committee, International Federation of Accountants.

Mayer E. (1986). Controlling-Konzepte. Perspektiven für 90er Jahre. Wiesbaden: Gabler.

Mayer E., Mann R. (1992). Controlling w twojej firmie. Warszawa: Wydawnictwo Prawnicze.

Nowak E., ed. (1996). Podstawy controlling. Wrocław: Wydawnictwo Akademii Ekonomicznej im. Oskara Langego we Wrocławiu.

Nowak E. (2011). System controllingu w przedsiębiorstwie. In: Nowak E. ed., Controlling w działalności przedsiębiorstwa, 2nd edition. Warszawa: Polskie Wydawnictwo Ekonomiczne.

Olech S. (1999). Tendencje rozwojowe controllingu. Controlling i Rachunkowość Zarzadcza w Firmie, no. 2, pp. 2-3.

Paul J. (2014). Beteiligungscontrolling und Konzerncontrolling. Wiesbaden: Springer Gabler.

Piontek J. (2012). Beschaffungscontrolling. In: Managementwissen für Studium und Praxis. München: Oldenbourg.

Radek M., Schwarz R. (2000). Zmiany w rachunkowości zarządczej w polskich przedsiębiorstwach $\mathrm{w}$ okresie transformacji systemu gospodarczego (na podstawie badań empirycznych). Zeszyty Teoretyczne Rachunkowości, no. 1 (57), pp. 58-83.

Rozporządzenie Ministra Pracy i Polityki Społecznej z dnia 27 kwietnia 2010 r. w sprawie klasyfikacji zawodów i specjalności na potrzeby rynku pracy oraz zakresu jej stosowania, Dz. U. no. 82/2010, poz. 537.

Sawicki K. (1992). Controlling a rachunkowość podmiotów gospodarczych. Zeszyty Teoretyczne Rady Naukowej, no. 21, pp. 23-33.

Sawicki K. (1999). Problemy stosowania controllingu w polskich przedsiębiorstwach. Zeszyty Teoretyczne Rady Naukowej, no. 48, pp. 98-105.

Schäffer U., Binder Ch. (2008). "Controlling" as an academic discipline: The development of management accounting and management control research in German-speaking countries between 1970 and 2003. Accounting History, vol. 13 (1), pp. 33-74. 
Schwetizer M., Friedl B. (1992). Beitrag zu einer umfassenden Controlling-Konzeption. In: Spermann K., Zur E. (Hrsg.), Controlling. Grundlagen-Informationssysteme-Anwendungen, Wiesbaden: Gabler, pp. 141-167.

Schulz E., Schulz W., Letmathe, P. (1993). Umweltcontrolling in der Praxis. In: Controlling, München: Vahlen.

Sobańska I. (1992). Od thumacza. In: Mayer E., Mann R. Controlling w twojej firmie. Warszawa: Wydawnictwo Prawnicze.

Sobańska I. (2002). Jak się zmienia praktyka rachunkowości zarządczej na przełomie XX i XXI wieku? (część II - Polska). Controlling i Rachunkowość Zarządcza, no. 1, pp. 6-11.

Sobańska I. (2010). Rachunkowość zarządcza. In: Sobańska I., ed., Rachunkowość zarządcza. Podejście operacyjne i strategiczne. Warszawa: Wydawnictwo C. H. Beck.

Sobańska I., Wnuk T. (2000). Zmiany w praktyce rachunkowości na przełomie XX i XXI wieku. Zeszyty Teoretyczne Rady Naukowej, no. 56, pp. 215-221.

Sobańska I., Szychta A, Świderska G. K., Kabalski P. (2010). Rachunkowość zarządcza a controlling. Rachunkowość, no. 3, pp. 59-62.

Sojak S., Gierusz J., Kozak P., Czerska E. (2007). Zestawienie prac habilitacyjnych i doktorskich z zakresu rachunkowości obronionych w latach 1948-2006, Zeszyty Teoretyczne Rachunkowości, no. 37 (93), pp. 5-112.

Sojak S., Czerska E. (2007). Zestawienie prac habilitacyjnych i doktorskich z zakresu rachunkowości obronionych w latach 2006-2012, Zeszyty Teoretyczne Rachunkowości, no. 37 (93), pp. 197-233.

Statements on Management Accounting. Definition of Management Accounting. (2008). Montvale: Institute of Management Accountants.

Szychta A. (1992). Rachunkowość jako narzędzie operatywnego i strategicznego controllingu. Zeszyty Teoretyczne Rady Naukowej, no. 20, pp. 32-36.

Szychta A. (2002). The scope of application of management accounting methods in Polish enterprises. Management Accounting Research, vol. 13, no. 4, pp. 401-418.

Szychta A. (2005). Rola współczesnych specjalistów do spraw rachunkowości zarządczej w świetle ewolucji jej zakresu i metod. Zeszyty Teoretyczne Rachunkowości, no. 25 (81), pp. 80-107.

Szychta A. (2007). Etapy ewolucji i kierunki integracji metod rachunkowości zarządczej. Łódź: Wydawnictwo Uniwersytetu Łódzkiego.

Szychta A. (2009). Changes in management accounting practice in Poland. In: Sobańska I., Nowak W. A. (eds.), Enterprise Accounting and Management under Globalization: recent Evidence from Poland and Lithuania. Łódź: Wydawnictwo Uniwersytetu Łódzkiego, pp. 7597.

Szychta A. (2011). Rachunkowość zarządcza jako działalność zawodowa w kontekście doświadczeń zagranicznych. Zeszyty Teoretyczne Rachunkowości, no. 62 (118), pp. 289312.

Świderska G. K. (2010). Controlling kosztów i rachunkowość zarządcza. Warszawa: MAC Consulting, Difin. 
Vollmuth H. J. (1993). Controlling. Planowanie, kontrola, zarzadzanie. Warszawa: Agencja Wydawnicza Placet.

Wilson R. M. S. (1995). Strategic Management Accounting. In: Ashton D., Hopper T., Scapens T. W. (eds.) Issues in Management Accounting. London: Prentice Hall, pp. 159190.

Wnuk T. (2005). Implementacja rachunku kosztów działań w średniej wielkości polskim przedsiębiorstwie. Zeszyty Teoretyczne Rachunkowości, no. 29 (85), pp. 122-153.

Wnuk-Pel T. (2011). Zastosowanie rachunku kosztów działań w przedsiębiorstwach w Polsce. Łódź: Wydawnictwo Uniwersytetu Łódzkiego.

\section{Internet sources}

O miesięczniku „Controlling i Rachunkowość Zarządcza”. http://www.econtrolling.explanator.pl/, access: 23.08.2016.

Perspective of the International Controller Association (ICV) and the International Group of Controlling (IGC) (2012).

https://www.igc-controlling.org/fileadmin/pdf/grundsatzposition_e.pdf, access: 25.08.2016.

Zeszyty Teoretyczne Rachunkowości, http://ztr.skwp.pl/index.php?p=1, access: 25.08.2016. 